\title{
Atmospheric circulation patterns associated with the variability of River Ammer floods: evidence from observed and proxy data
}

\author{
Norel Rimbu ${ }^{1}$, Markus Czymzik ${ }^{2,3}$, Monica Ionita ${ }^{1,4}$, Gerrit Lohmann ${ }^{1,4}$, and Achim Brauer ${ }^{2}$ \\ ${ }^{1}$ Alfred Wegener Institute Helmholtz Centre for Polar and Marine Research, Bremerhaven, Germany \\ ${ }^{2}$ GFZ German Research Centre for Geosciences, Climate Dynamics and Landscape Evolution, Potsdam, Germany \\ ${ }^{3}$ Lund University, Department of Geology, Lund, Sweden \\ ${ }^{4}$ MARUM - Center for Marine Environmental Sciences, University of Bremen, Bremen, Germany \\ Correspondence to: Norel Rimbu (norel.rimbu@awi.de)
}

Received: 5 August 2015 - Published in Clim. Past Discuss.: 21 September 2015

Revised: 19 January 2016 - Accepted: 27 January 2016 - Published: 23 February 2016

\begin{abstract}
The relationship between the frequency of River Ammer floods (southern Germany) and atmospheric circulation variability is investigated based on observational Ammer River discharge data back to 1926 and a flood layer time series from varved sediments of the downstream Lake Ammer for the pre-instrumental period back to 1766. A composite analysis reveals that, at synoptic timescales, observed River Ammer floods are associated with enhanced moisture transport from the Atlantic Ocean and the Mediterranean towards the Ammer region, a pronounced trough over western Europe as well as enhanced potential vorticity at upper levels. We argue that this synoptic-scale configuration can trigger heavy precipitation and floods in the Ammer region. Interannual to multidecadal increases in flood frequency, as detected in the instrumental discharge record, are associated with a wave train pattern extending from the North Atlantic to western Asia, with a prominent negative center over western Europe. A similar atmospheric circulation pattern is associated with increases in flood layer frequency in the Lake Ammer sediment record during the pre-instrumental period. We argue that the complete flood layer time series from Lake Ammer sediments covering the last 5500 years contains information about atmospheric circulation variability on interannual to millennial timescales.
\end{abstract}

\section{Introduction}

Flood events are natural disasters which cause important economic losses. Therefore, the variability and predictability of flood occurrences have been addressed in many research studies (e.g., Jacobeit et al., 2003; Czymzik et al., 2010; Peña et al., 2015; Schillereff et al., 2014; Ionita et al., 2008, 2015).

Recent studies (Corella et al., 2014, and reference therein) have identified pronounced temporal variability in the occurrence of heavy-precipitation and flood events using instrumental and environmental proxy time series. For example, during the last decades, the frequency of heavy precipitation in central Europe has increased (Zolina et al., 2008), while winter precipitation extremes in coastal Mediterranean sites have decreased (Toreti et al., 2010). On longer timescales, flood frequency in different parts of Europe is characterized by distinct multidecadal to centennial variability (Czymzik et al., 2010; Corella et al., 2014). Understanding flood responses to climate forcing is essential to anticipate possible changes in flood dynamics related to anthropogenic climate change.

The present study focuses on flood variability of the River Ammer, located in the northern pre-Alpine region. Heavyprecipitation variability in the Alpine region has been related to various internal or external forcing on different scales. On the mesoscale, atmospheric flow is strongly influenced by local topography triggering convective precipitation. On the synoptic scale, high-potential-vorticity intrusions over western Europe play an important role in the forcing of heavy precipitation along the southern Alpine rim (Schlemmer et al., 2010, and references therein). Furthermore, heavy precipitation and floods in the Ammer region are related to largescale circulation patterns. Czymzik et al. (2010) related major River Ammer floods (southern Germany) to the occurrence of particularly flood-prone weather regimes. Glur et 
al. (2013) associated flood frequency increases in the Alpine realm with periods of colder climate with a higher occurrence of westerly and $\mathrm{Vb}$ tracks. Toreti et al. (2013) show that the occurrence of debris flows in the Swiss Alps is connected to two synoptic atmospheric circulation patterns which favor anomalous southerly flow towards this area and high potential instability. Interannual to multidecadal variability of heavy precipitation and flood events in the Alpine region are also related to large-scale atmospheric teleconnection patterns. Peña et al. (2015) emphasized the role of the Summer North Atlantic Oscillation (SNAO) in generating flood variability in Swiss rivers. The east Atlantic (EA) pattern and SNAO modify the frequency of atmospheric circulation patterns controlling debris flow occurrences in the Swiss Alps (Toreti et al., 2013). Flood frequency variability in the pre-Alps on multidecadal timescales was further related to changes in solar activity (Czymzik et al., 2010; Peña et al., 2015).

In this study we investigate the relationship between the frequency of River Ammer floods and atmospheric circulation. Identifying the atmospheric mechanisms behind River Ammer floods allows a better interpretation of the flood layer record from varved Lake Ammer sediments reaching back the last 5500 years (Czymzik et al., 2010, 2013). Flood layers form during Ammer River floods, when detrital catchment material is eroded, transported into the lake and deposited on the lake floor when transport capacity of the inflowing turbidity diminishes in the water body. Here we use both instrumental River Ammer discharge and Lake Ammer flood layer data in combination with long-term observed and reconstructed climatic fields to investigate the relationship between River Ammer flood frequency and atmospheric circulation. This will improve the interpretation of River Ammer flood frequency changes as presented in previous studies (e.g., Czymzik et al., 2010).

The paper is organized as follows. Data and methods are presented in Sect. 2. The main results follow in Sect. 3. In Sect. 3.1 the synoptic-scale patterns that cause River Ammer floods are presented. The atmospheric circulation pattern associated with interannual to multidecadal increases in River Ammer flood frequency during the observational period are presented in Sect. 3.2. The atmospheric circulation patterns associated with flood layer frequency increases during the instrumental and pre-instrumental period, with focus on the similarity with the corresponding patterns derived from observational data, are described in Sect. 3.3. A discussion and the main conclusions follow in Sect. 4.

\section{Data and methods}

The River Ammer arises in the Bavarian Alps, southern Germany, (Fig. 1a) and flows northward to Lake Ammer (Czymzik et al., 2010). The river is relatively small $(84 \mathrm{~km}$ length) and has a catchment area of $\sim 700 \mathrm{~km}^{2}$. The Ammer (a)

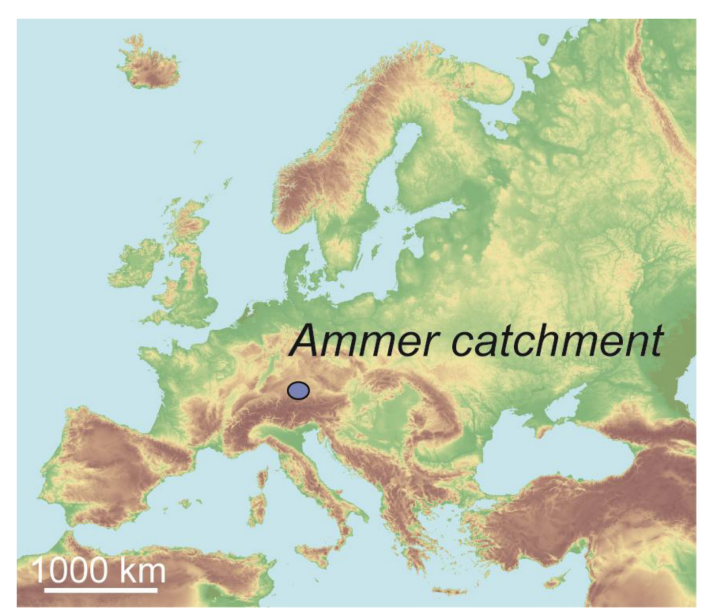

(b)

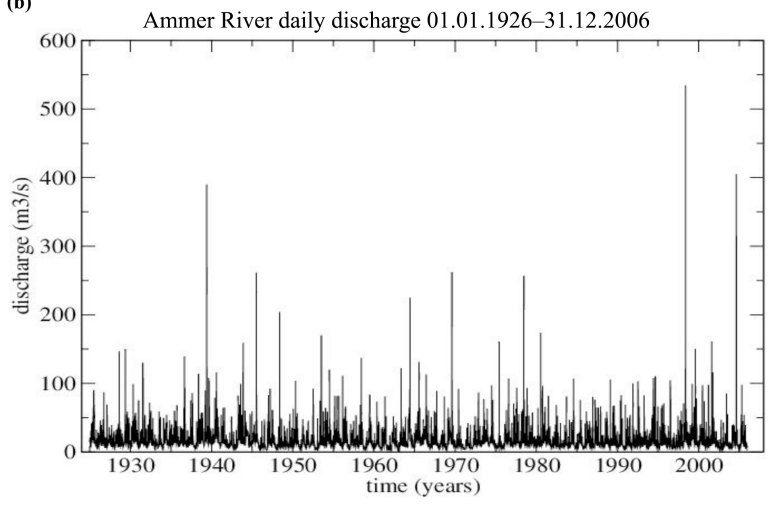

Figure 1. (a) Geographical location of the Ammer catchment and (b) time series of the observed mean daily River Ammer runoff during the period 1926-2006.

catchment is located in the transition zone between maritime North Atlantic and continental climate, influenced by both frequent cyclonic westerly airflow and atmospheric blocking through high-pressure fields (Petrow and Merz, 2009). The annual Ammer flow regime is characterized by strong seasonal variations with a maximum during late spring and summer (Czymzik et al., 2010).

The main quantity analyzed here is the mean daily Ammer River runoff recorded at gauge Weilheim (Bayerisches Landesamt für Umwelt, 2007) during the period 1926 to 2006. Although River Ammer floods occur mainly from May to August (Czymzik et al., 2010; Ludwig et al., 2003), we analyze the runoff data over the entire year. As a proxy for River Ammer floods in the pre-instrumental period, we used the flood layer record from Lake Ammer described in Czymzik et al. (2010, 2013). This record was downloaded from the online environmental database PANGAEA (www.pangaea.de).

The atmospheric circulation patterns associated with River Ammer floods in the instrumental discharge and flood layer record are based on annual mean $500 \mathrm{hPa}$ geopotential height (Z500) and $850 \mathrm{hPa}$ temperature (T850) anomalies calculated 
using 20th Century Reanalysis, version 2 (hereafter 20CR) data (Compo et al., 2011) starting in 1871. The temperature pattern associated with River Ammer floods in the discharge record over the period 1926-2006 is based on the University of Delaware air temperature and precipitation data set (UDel_AirT_Precip) provided by the NOAA/OAR/ESRL PSD, Boulder, Colorado, USA (available at http://www.esrl. noaa.gov/psd/).

Also from the 20CR database we used daily fields of specific humidity $(q)$, zonal $(u)$ and meridional $(v)$ wind. These quantities were used to calculate vertically integrated water vapor transport (IWT) over the period 1926-2006. The magnitude of daily IWT is calculated in an Eulerian framework as follows:

$\mathrm{IWT}=\left[\left(\int_{1000}^{300} q u \frac{\mathrm{d} p}{g}\right)^{2}+\left(\int_{1000}^{300} q v \frac{\mathrm{d} p}{g}\right)^{2}\right]^{1 / 2}$,

where $g$ is the acceleration due to gravity. The vertical integration is limited to the 1000 to $300 \mathrm{hPa}$ pressure interval because specific humidity in the 20CR data is negligible above $300 \mathrm{hPa}$. Daily Z500 were used to establish the synopticscale atmospheric circulation pattern associated with high $\left(>125 \mathrm{~m}^{3} \mathrm{~s}^{-1}\right.$ ) daily Ammer River runoff. The $250 \mathrm{hPa}$ divergence field, used to identify regions with anomalous vertical motions, is calculated from the daily $250 \mathrm{hPa}$ zonal and meridional wind fields.

Daily $200 \mathrm{hPa}$ potential vorticity (PV) fields, for the period 1979-2006, were obtained from ERA-Interim (Dee et al., 2011) database. The upper-level PV anomalies are strongly related to extreme precipitation events (Schlemmer et al., 2010; Krichak et al., 2014) and are used here to find possible atmospheric mechanisms behind River Ammer floods at synoptic timescales.

We also use Z500 and air temperature $(T)$ reconstructions for the period 1766 to 1870 , extracted from the reconstructed gridded meteorological data set of Casty et al. (2007), to derive flood related patterns prior $20 \mathrm{CR}$ data.

\section{Results}

\subsection{Synoptic-scale atmospheric patterns associated with River Ammer floods}

The time series of mean daily River Ammer discharge (Fig. 1b) shows no significant linear trend during the period 1926-2006. However, visual inspection of the discharge time series (Fig. 1b) reveals distinct interannual to multidecadal flood frequency variations. Daily River Ammer discharge ranges between 2.6 and $534.6 \mathrm{~m}^{3} \mathrm{~s}^{-1}$. Mean discharge over the analyzed period is $15 \mathrm{~m}^{3} \mathrm{~s}^{-1}$, while the lower and upper quartiles are 8.9 and $18.3 \mathrm{~m}^{3} \mathrm{~s}^{-1}$, respectively. A discharge of $125 \mathrm{~m}^{3} \mathrm{~s}^{-1}$ is considered as a threshold for flood layer deposition in the Lake Ammer sediment record. Above this dis-
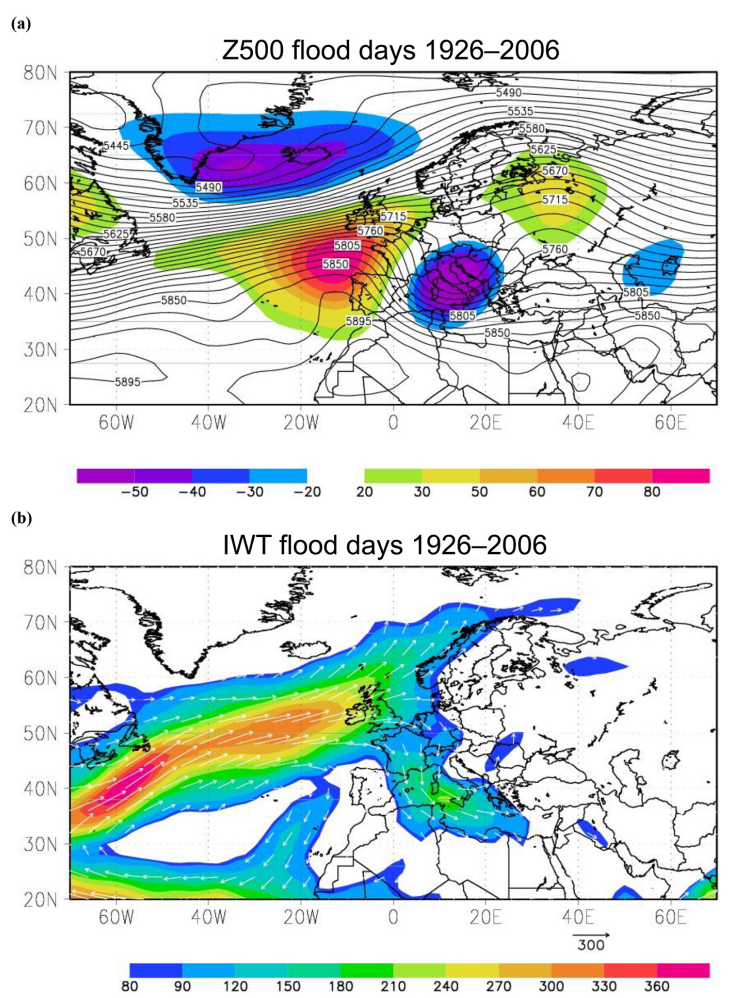

Figure 2. (a) Composite map of daily $500 \mathrm{hPa}$ geopotential height (contour) and anomalies (shaded) corresponding to River Ammer floods (discharge higher than $125 \mathrm{~m}^{3} \mathrm{~s}^{-1}$ ) for the period 1926-2006 and (b) composite map of IWT for flood days (vector) and its magnitude (color). Units: Z500 (m) and IWT $\left(\mathrm{kg} \mathrm{m}^{-1} \mathrm{~s}^{-1}\right)$.

charge threshold the deposition of a flood layer during a flood is very likely (Czymzik et al., 2010).

During the 81-year period 1926-2006, 32 days with River Ammer discharge higher than $125 \mathrm{~m}^{3} \mathrm{~s}^{-1}$ were generated by 20 independent flood events (Fig. 1b). The composite map of daily Z500 anomalies during these River Ammer flood days (Fig. 2a, shaded) shows two centers of positive Z500 anomalies, northwest of the Iberian Peninsula and north of the Black Sea, and two negative Z500 anomaly centers: over the Iceland region and southern Europe. The anomaly pattern (Fig. 2a, shaded) contains elements of the two synoptic patterns associated with debris flows in the Swiss Alps as described by Toreti et al. (2013) (their Fig. 2). The corresponding daily Z500 composite map (Fig. 2a, contours) depicts a wave-like structure with a pronounced trough over western and central Europe as well as two ridges over the eastern North Atlantic and northeastern Europe. The IWT composite map for days with mean daily River Ammer discharge higher than $125 \mathrm{~m}^{3} \mathrm{~s}^{-1}$ (Fig. 2b) depicts enhanced moisture transport from the Atlantic towards the northern Alpine flank, with the Ammer region being located along the axis of the highest IWT (Fig. 2b). To link this moisture transport to local heavy precipitation, a mechanism is needed to lift up the 
wet air. Previous studies (Browning, 1997; Schlemmer et al., 2010; Krichak et al., 2014) have emphasized a strong relationship between PV anomalies and precipitation extremes. Southern intrusions of air with relatively high PV in the upper troposphere or lower stratosphere are commonly accompanied by a local lowering of the tropopause, intense vertical motions, high vertically integrated water vapor transport, rapid cyclogenesis, intense convection and heavy rainfall (e.g., Krichak et al., 2014). Therefore, we investigate the $250 \mathrm{hPa}$ atmospheric circulation and $200 \mathrm{hPa}$ PV fields associated with flood days with discharge higher than $125 \mathrm{~m}^{3} \mathrm{~s}^{-1}$. The composite map of $250 \mathrm{hPa}$ circulation associated with daily River Ammer floods indicates a continuous high-speed wind system with two regional maxima: in the Atlantic and African region (Fig. 3a). A pronounced convergence zone, which is indicative of descendent motions, is reflected between the exit region of the Atlantic branch and the entrance region of the African branch of the jet (Fig. 3a, dashed contour lines). A pronounced divergence zone is visible above the Ammer region (Fig. 3a, solid contour lines). This is indicative of strong vertical motions and heavy rainfall. The poleward side of a jet exit region is preferred for cyclonic growth, which in turn induces heavy rainfall events (Hoskins et al., 1978). A similar synoptic pattern was found to be responsible for high streamflow anomalies of the Rhine River (Ionita et al., 2012). Consistent with Fig. 3a, a region of relatively high PV is identified at $200 \mathrm{hPa}$ level (Fig. 3b). Both divergence (Fig. 3a) and high PV (Fig. 3b) regions are relatively small, consistent with a strong local character of the heavy-precipitation events.

To better assess the atmospheric circulation patterns associated with River Ammer floods as revealed by the composite analysis, we exemplarily investigate the Z500, IWT and PV responses to the River Ammer flood on 19 and 20 July 1981 (Fig. 4). During 19 July 1981 a prominent trough dominates central and western Europe (Fig. 4a). The IWT (Fig. 4b) shows narrow bands over the eastern North Atlantic and western Europe, similar to atmospheric rivers (e.g., Lavers et al., 2012). An intrusion of relatively high PV from the north is recorded at the $200 \mathrm{hPa}$ level (Fig. 4c). In addition, a relatively narrow stream of high-PV flows from the Mediterranean area to central Europe (Fig. 4c). This high-PV stream is accompanied by exceptional northward transport of moisture from the Mediterranean (Fig. 4b). On 20 July 1981 the axis of the trough above Europe remains in a similar position (Fig. 4d), while the structure of the IWT changes significantly (Fig. 4e) compared to the previous day (Fig. 4b). Furthermore, the high-PV center above the Ammer region tends to isolate from the high-PV pool at higher latitudes (Fig. 4f). To conclude, the composite situation during the River Ammer flood on 19 an 20 July 1981 shares common characteristics with most River Ammer floods $>125 \mathrm{~m}^{3} \mathrm{~s}^{-1}$ during the period 1926-2006. However, there are also River Ammer floods that are associated with atmospheric circulation patterns and mechanisms different than those presented in this
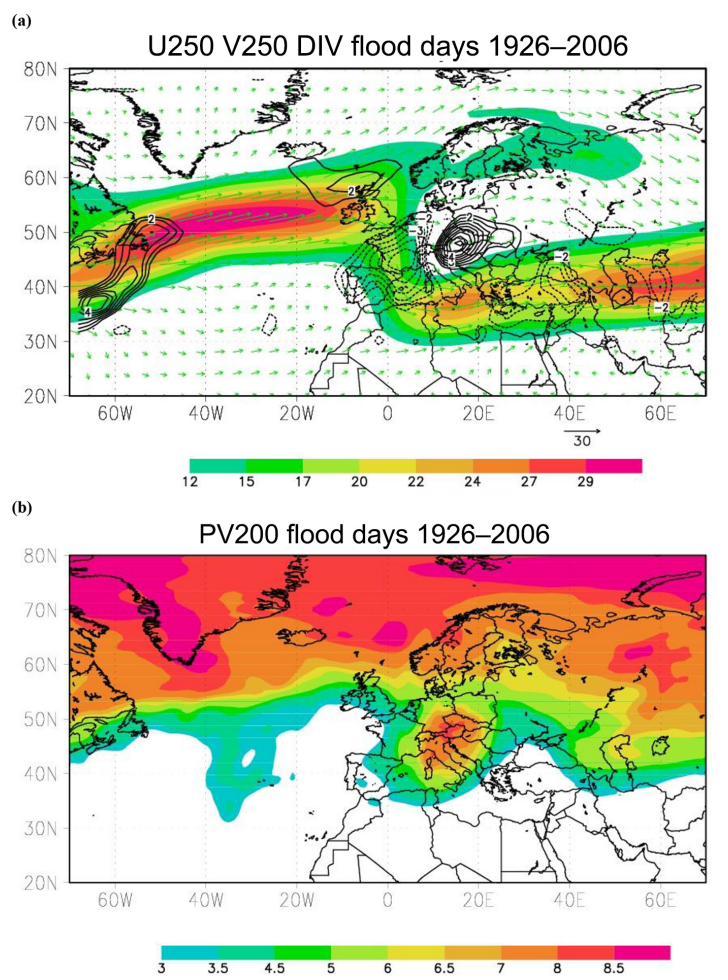

Figure 3. Composite map of (a) the $250 \mathrm{hPa}$ wind (vector), its magnitude (color) and divergence (contour) for Ammer flood days for the period 1926-2006 and (b) composite map of $200 \mathrm{hPa}$ potential vorticity for flood days during 1979-2006. Units: U250 $\left(\mathrm{m} \mathrm{s}^{-1}\right)$, divergence $\left(10^{-6} \mathrm{~s}^{-1}\right)$ and potential vorticity (PVU).

case study. For example, the circulation associated with the River Ammer flood on 14 June 1959 (not shown) is a typical omega-blocking circulation with heavy precipitation produced on the eastern side of the block. However, most of the River Ammer floods (discharge $>125 \mathrm{~m}^{3} \mathrm{~s}^{-1}$ ) are related to synoptic patterns that are similar to those that characterize the 19 to 20 July 1981 flood, which is consistent with the composite analysis shown in Fig. 2.

\subsection{Observed River Ammer flood frequency and atmospheric circulation back to 1926}

The annual frequency of River Ammer floods, defined as the number of days when mean daily Ammer River discharge is higher than $125 \mathrm{~m}^{3} \mathrm{~s}^{-1}$, shows pronounced decadal to multidecadal variability (Fig. 5a) with increased flood frequencies from 1940 to 1960 and during the 1980s and 2000s. The composite map of annual Z500 anomalies for the years when River Ammer flood frequency is different from zero (Fig. 5b) shows a spatial structure that bears some similarities to the corresponding synoptic-scale pattern (Fig. 2a). Positive Z500 anomalies prevail in the North Atlantic region and northeastern Europe, while negative Z500 anomalies dominate over a broad area from Iceland to the central 
(a)

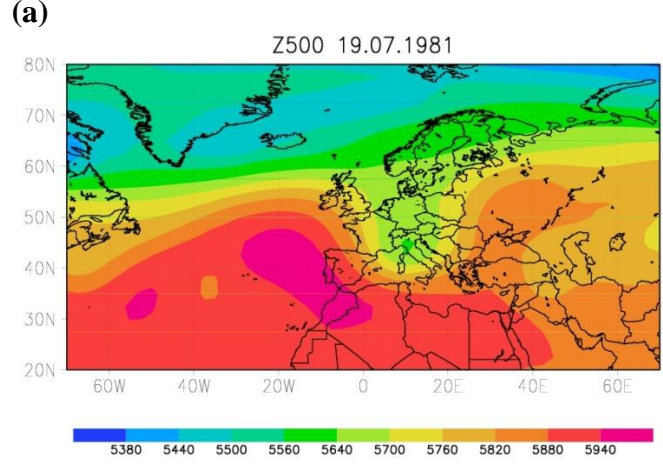

(b)

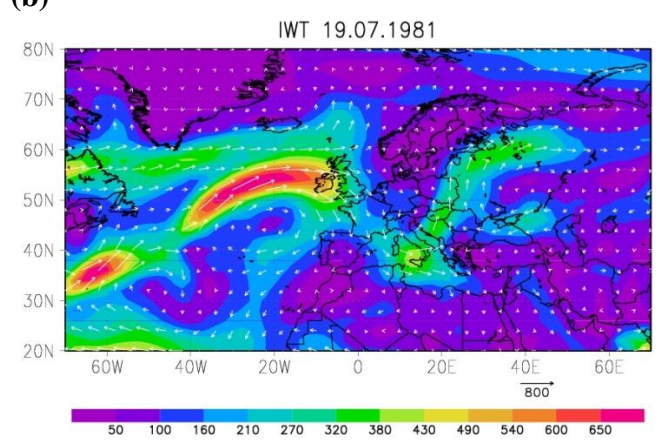

(c)

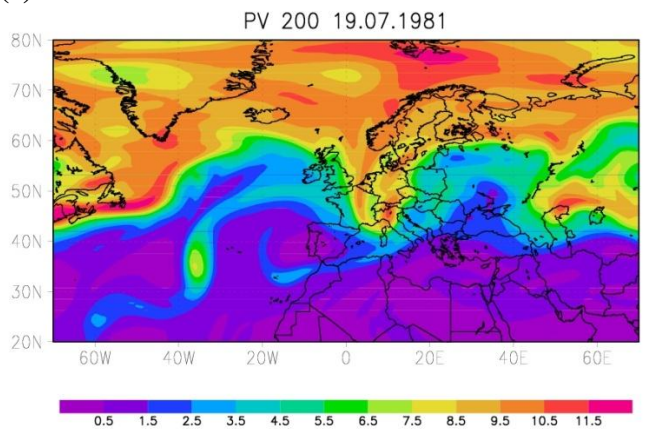

(d)

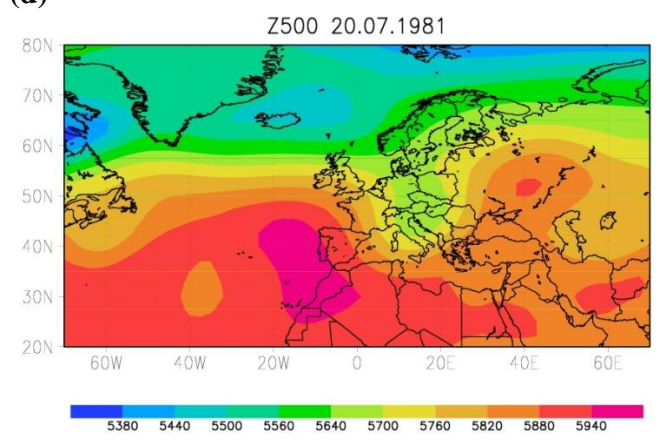

(e)

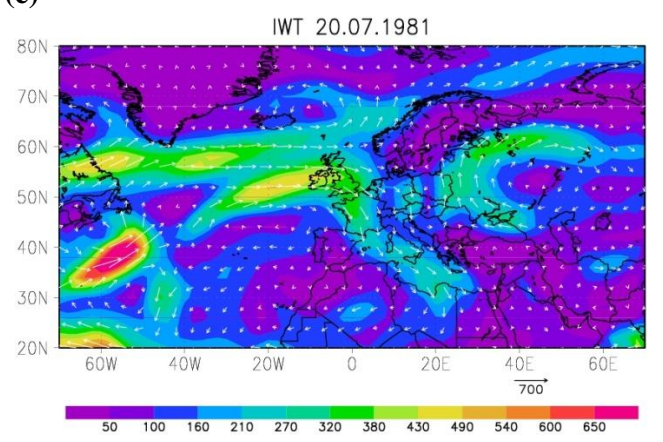

(f)

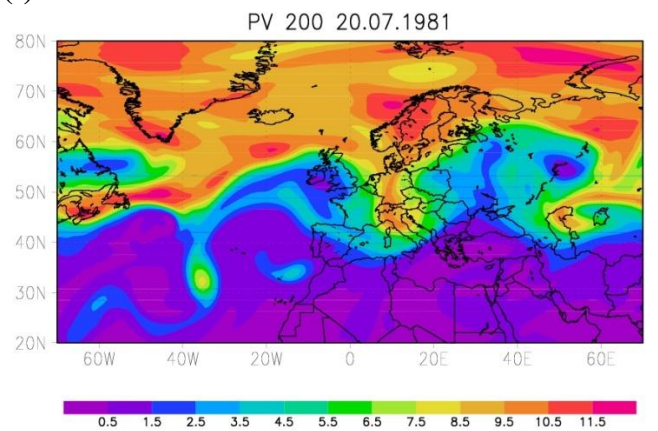

Figure 4. Synoptic-scale meteorology during the River Ammer flood days 19 and 20 June 1981: (a) Z500, (b) IWT and (c) PV for 19 June 1981; (d, e, f) as in (a, b, c) but for 20 June 1981. Units: Z500 (m), IWT $\left(\mathrm{kg} \mathrm{m}^{-1} \mathrm{~s}^{-1}\right)$ and PV (PVU).

Mediterranean (Fig. 5b). This Z500 anomaly pattern resembles the dominant atmospheric circulation anomaly pattern associated with the occurrence of debris flows in the southern Swiss Alps as described by Toreti et al. (2013) (their Fig. 2a). The spatial temperature pattern associated with River Ammer floods (Fig. 5c) is consistent with the corresponding atmospheric circulation pattern (Fig. 5a) depicting negative anomalies over central and southern Europe and strong positive anomalies over northeastern Europe.

\subsection{Flood layer frequency and atmospheric circulation back to 1766}

In the following we investigate the relationship between changes in flood layer frequency in the Lake Ammer sediment record and atmospheric circulation. The flood layer record used in this study is described in Czymzik et al. (2010). We investigate the atmospheric circulation patterns associated with flood layer variability for the period 1871-1999 using 20CR data and for the period 1766-1870 using reconstructed gridded meteorological data (Casty et al., 2007).

The Lake Ammer flood layer record for the period 18711999 (Fig. 6a) shows increased flood frequencies in the 1980s and 1950s, comparable to the instrumental River Ammer discharge record in the overlapping parts (Fig. 5a). Older periods of enhanced flood frequency occur during the 1920s and 1880s (Fig. 6a). The average Z500 anomalies for all years with a deposited flood layer during this period (Fig. 6b) depict a pattern similar to that based on the instrumental River Ammer flood record (Fig. 5b). A well-defined wave 
(a)

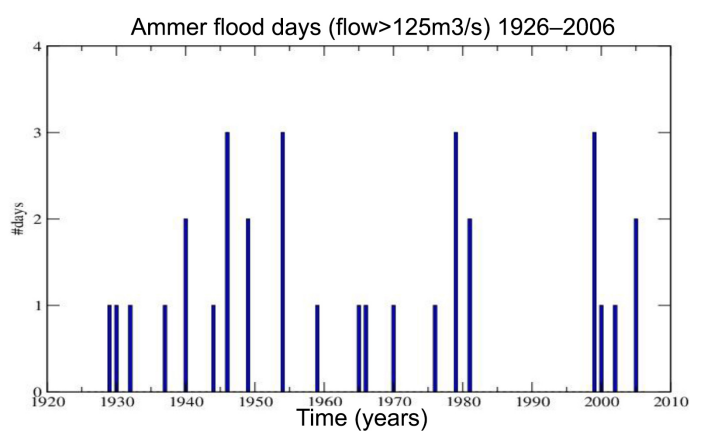

(b)

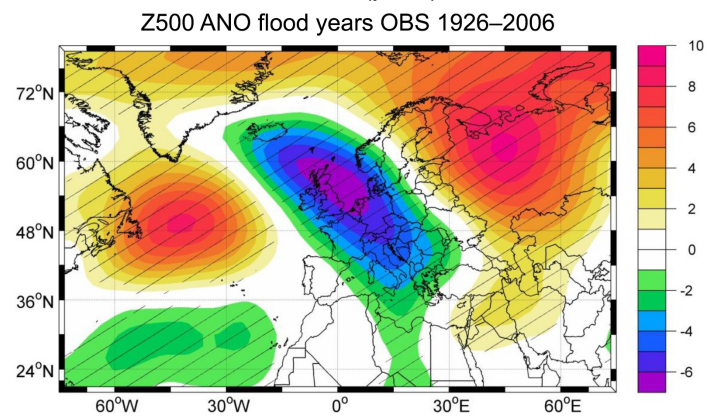

(c)

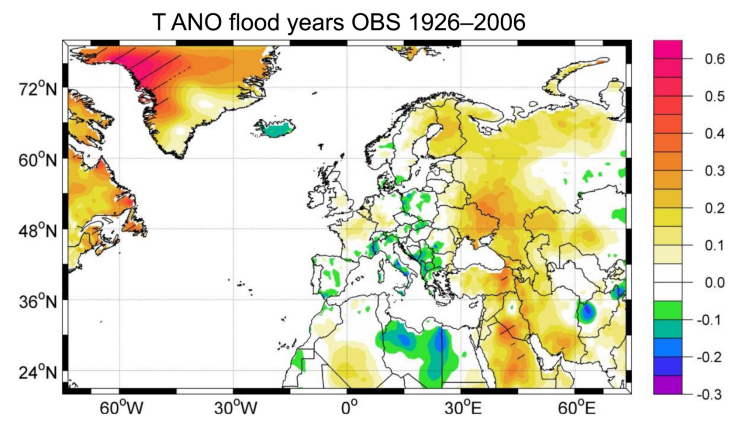

Figure 5. (a) Observed River Ammer flood frequency (daily discharge higher than $125 \mathrm{~m}^{3} \mathrm{~s}^{-1}$ ) and (b) composite map of Z500 and (c) air temperature anomalies for flood years. Hatched regions: anomalies significantly different from zero (90\% level). Units: $\mathrm{Z} 500(\mathrm{~m})$ and $T\left({ }^{\circ} \mathrm{C}\right)$.

train that appears in the $850 \mathrm{hPa}$ temperature field (Fig. 6c) is also visible during the period of instrumental River Ammer discharge measurements (Fig. 5c).

During the period 1766-1870, the flood layer time series shows also distinct decadal to multidecadal frequency variations (Fig. 7a) and higher flood layer frequencies during the second part of the 19th century, coincident with high flood frequencies in the greater Alpine region (Glur et al., 2013). Both Z500 (Fig. 7b) and temperature (Fig. 7c) patterns during the period $1766-1870$ are similar to the corresponding patterns based on 20CR data for the period 1871-1999 (Fig. 6b and c). (a)

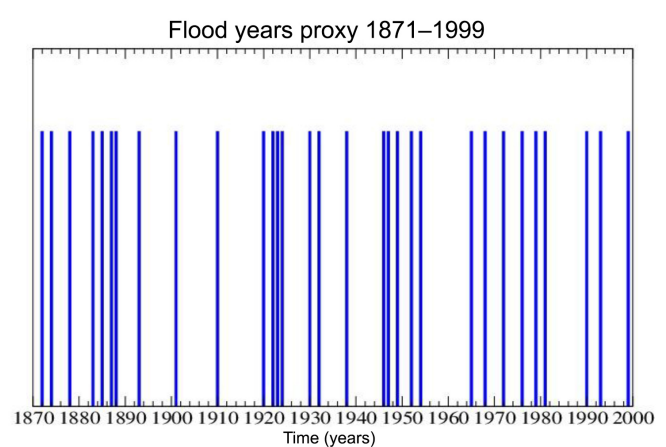

(b)

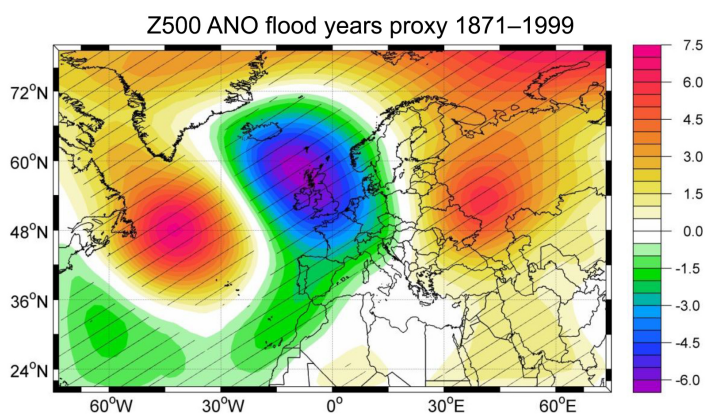

(c)

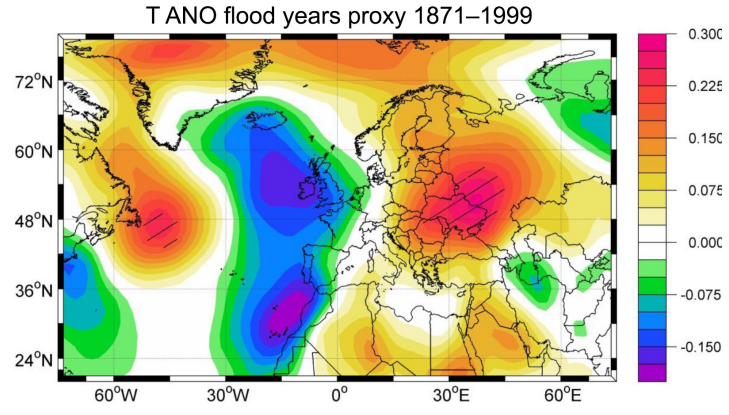

Figure 6. (a) River Ammer flood layer record for the period 18711999 (see text for details). Vertical bars depict years with flood layer. Composite map of (b) Z500 and (c) $T$ anomalies for years with flood layer as shown in (a). Hatched regions: anomalies significantly different from zero (90\% level). Units: Z500 (m) and T $\left({ }^{\circ} \mathrm{C}\right)$.

\section{Discussion and conclusions}

We have shown that the majority of River Ammer floods (discharge higher than $125 \mathrm{~m}^{3} \mathrm{~s}^{-1}$ ) are associated with a pronounced ridge (trough) over the east Atlantic (western Europe), enhanced moisture transport towards the Ammer catchment and relatively high potential vorticity at upper levels $(200 \mathrm{hPa})$. The upper-level positive PV anomalies are associated with strong vertical motions, a lowered tropopause and heavy precipitation in the Ammer region. Czymzik et al. (2010) have shown that River Ammer flood events (discharge higher than $125 \mathrm{~m}^{3} \mathrm{~s}^{-1}$ ) are related to specific atmospheric circulation types. Five circulation types, as classified in the weather catalog of Gersterngarbe and Werner (2005), could be attributed to more than one flood event during the 
(a)

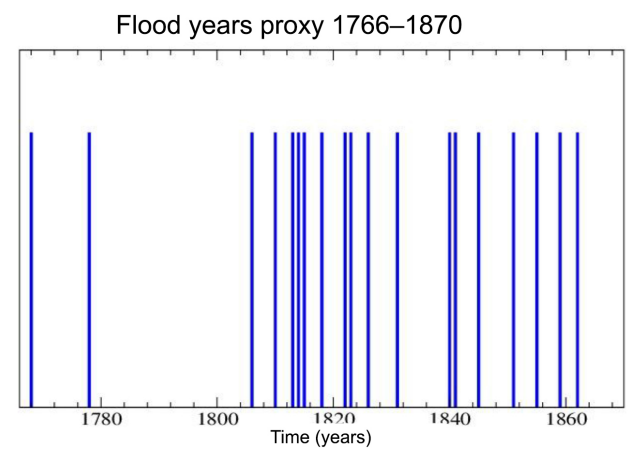

(b)

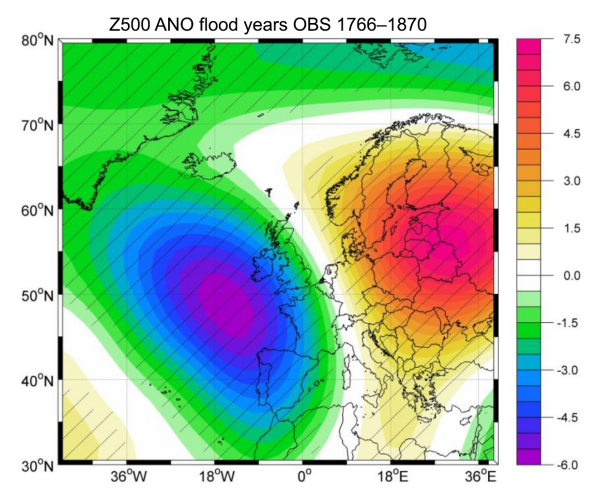

(c)

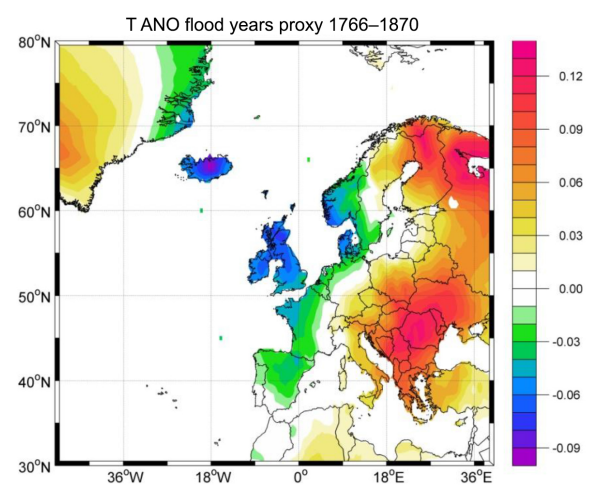

Figure 7. Same as in Fig. 6 but for the period 1766-1870.

period 1926-1999. Four of the five atmospheric circulation types are compatible with a northwest-to-southeast or northto-south trajectory of cyclones crossing the Ammer region (Czymzik et al., 2010, their Fig. 10). This is consistent with our IWT pattern and the corresponding $200 \mathrm{hPa}$ PV pattern associated with floods in the instrumental River Ammer discharge record.

Floods over Europe are related to various moisture sources. For central European floods that occurred in June 2013, the main source of moisture was the land along the track of the three consecutive cyclones that generated very high rainfall amounts in central Europe (Grams et al., 2014). Continental moisture sources also played an important role in eastern European flooding in May 2010, in addition to moisture sources in the North Atlantic and Mediterranean (Winschall et al., 2014). Our analysis suggests that the
North Atlantic Ocean is the main moisture source for River Ammer floods. Therefore the flood layer record from Lake Ammer could be used to obtain information about patterns of moisture transport from the North Atlantic towards Europe during the last millennia.

Under current climate conditions heavy precipitation in the Alpine region is associated with zonal westerly or meandering circulation regimes, e.g., the $\mathrm{Vb}$ cyclone track (e.g., Zängl, 2007). The $\mathrm{Vb}$ track is characterized by low-pressure systems moving northeastward from the Adriatic Sea into continental Europe, causing orographic rainfall and potentially severe flooding along the Alpine crest (e.g., Schlemmer et al., 2010) and in central Europe (Ionita et al., 2015). The synoptic-scale pattern associated with Ammer floods (Fig. 2a) is consistent with that provided by Schlemmer et al. (2010) and Ionita et al. (2015). Moreover, it contains elements of the synoptic-scale patterns associated with debrisflow events in the southern Swiss Alps (Toreti et al., 2013). Glur et al. (2013) propose that a more southerly and weaker subtropical high-pressure zone favors the occurrence of $\mathrm{Vb}$ circulation patterns. In particular, during the late 19th century, which was characterized on average by cooler summers, frequent $\mathrm{Vb}$ situations led to a higher frequency of floods in the Alpine region, coincident with higher flood frequencies in the Ammer region. The high flood frequency of the River Ammer, as derived from both River Ammer discharge and Lake Ammer flood layer data, is related to increased frequency of southerly intrusions of high PV favoring strong vertical motions and heavy rainfall in the region. However, higher River Ammer flood frequencies are recorded during colder conditions over western and central Europe and warmer conditions over eastern Europe (Fig. 5). Cooler conditions over western and central Europe are induced by enhanced advection of relatively cold air from the northwest, while warmer conditions over northeastern Europe are related to a flow of warm air from the southeast (Fig. 5). Another forcing factor for positive temperature anomalies over northeastern Europe is the negative cloudiness anomalies which dominate this region during high-flood-frequency periods (not shown).

Variability of heavy precipitation and floods in the Alpine region was related to various atmospheric teleconnection patterns, like the North Atlantic Oscillation (Swierczynski et al., 2012), the North Atlantic Oscillation and east Atlantic pattern (Toreti et al., 2013) and the Summer North Atlantic Oscillation (Peña et al., 2015). The atmospheric circulation anomaly pattern associated with River Ammer flooding projects well on the negative phase of the east Atlanticwestern Russia (EA-WR) pattern, a three-center east-west wave train with one center of action close to the British islands, one in northeast China, and one center with an opposite sign near the Caspian Sea (e.g., Barnston and Livezey, 1987). Indeed, the analysis of the annual EA-WR index based on 20CR data reveals that the frequency of the negative phase of the EA-WR pattern is significantly higher than 
the frequency of its positive phase during River Ammer flood years from 1871 to 1999 (not shown). Therefore, the Lake Ammer flood layer record might provide the chance to reconstruct changes in the polarity of the EA-WR during the late Holocene. In addition, we conclude that the Lake Ammer flood layer record (Czymzik et al., 2010, 2013) might be used to deduce information about past change in specific moisture transport and atmospheric circulation patterns. In particular, the flood layer record from varved Lake Ammer sediments can be used to reconstruct the frequency of highpotential-vorticity intrusions over western Europe during the last millennia.

Acknowledgements. This study is promoted by Helmholtz funding through the Polar Regions and Coasts in the Changing Earth System (PACES) program of the AWI. Funding by the Helmholtz Climate Initiative REKLIM and the Excellence Cluster Marum (OC3 "The Ocean in the Earth System" high- and low-latitude atmosphere-ocean interactions) are gratefully acknowledged. M. Czymzik was partly funded by the Swedish Research Council (VR grant to RM:Dnr:2013-8421). We thank the data contributors for making their data available to the public.

Edited by: E. Zorita

\section{References}

Barnston, A. G. and Livezey, R. E.: Classification, seasonality and persistence of low-frequency atmospheric circulation patterns, Mon. Weather Rev., 115, 1083-1126, 1987.

Bayerisches Landesamt fur Umwelt: Daily River Ammer runoff data from 1926 to 2006, Munich, Germany, 2007.

Browning, K. A.: The dry intrusion perspective of extra-tropical cyclone development, Meteorol. Appl., 4, 317-324, 1997.

Casty, C., Raible, C. C., Stocker, T. F., Luterbacher, J., and Wanner. H.: A European pattern climatology 1766-2000, Clim. Dynam., 29, 791-805, doi:10.1007/s00382-007-0257-6, 2007.

Compo, G. P., Whitaker, J. S., Sardeshmukh, P. D., Matsui, N., Allan, R. J., Yin, X., Gleason, B. E., Vose, R. S., Rutledge, G., Bessemoulin, P., Brönnimann, S., Brunet, M., Crouthamel, R., Grant, A. N., Groisman, P. Y., Jones, P. D., Kruk, M. C., Kruger, A. C., Marshall, G. J., Maugeri, M., Mok, H. Y., Nordli, Ø., Ross, T. F., Trigo, R. M., Wang, X. L., Woodru, S. D., and Worley, S. J.: The Twentieth Century Reanalysis Project, Q. J. Roy. Meteor. Soc., 137, 1-28, doi:10.1002/qj.776, 2011.

Corella, J. P., Benito, G., Rodriguez-Lloveras, X., Brauer, A., and Valero-Garcés, B. L.: Annually-resolved lake record of extreme hydro-meteorological events since AD 1347 in NE Iberian Peninsula, Quaternary Sci. Rev., 93, 77-90, doi:10.1016/j.quascirev.2014.03.020, 2014.

Czymzik, M., Dulski, P., Plessen, B., von Grafenstein, U., Naumann, R., and Brauer, A.: A 450 year record of spring-summer flood layers in annually laminated sediments from Lake Ammersee (southern Germany), Water Resour. Res., 46, W11528, doi:10.1029/2009WR008360, 2010.

Czymzik, M., Brauer, A., Dulski, P., Plessen, B., von Grafenstein, U., Naumann, R., and Scheffler, R.: Orbital and solar forcing of shifts in Mid- to Late Holocene flood intensity from varved sediments of pre-alpine Lake Ammersee (southern Germany), Quaternary Sci. Rev., 61, 96-110, 2013.

Dee, D. P., Uppala, S. M., Simmons, A. J., Berrisford, P., Poli, P., Kobayashi, S., Andrae, U., Bal-maseda, M. A., Balsamo, G., Bauer, P., Bechtold, P., Beljaars, A. C. M., van de Berg, L., Bidlot, J., Bormann, N,. Delsol, C., Dragani, R., Fuentes, M., Geer, A. J., Haimberger, L., Healy, S. B., Hersbach, H., Hólm, E. V., Isaksen, L., Kållberg, P., Köhler, M., Matricardi, M., McNally, A. P., Monge-Sanz, B. M., Morcrette, J.-J., Park, B.-K., Peubey, C., de Rosnay, P., Tavolato, C., Thépaut, J.-N., and Vitart, F.: The ERA-interim reanalysis: configuration and performance of the data assimilation system, Q. J. Roy. Meteor. Soc., 137, 553-597, doi:10.1002/qj.828, 2011.

Gersterngarbe, F.-W. and Werner, P. C.: Katalog der Grosswetterlagen Europas (1881-2004) nach Paul Hess and Helmut Brezowsky, verbesserte and ergänzte Auflage, Rep. Issue 6, Potsdam Inst. For Clim. Impact Res., Potsdam, Germany, 2005.

Glur, L., Stefanie, B. W., Buntgen, U., Gilli, A., Haug, G. H., Schar, C., Beer, J., and Ansel-metti, F. S.: Frequent floods in the European Alps coincide with cooler periods of the past 2500 years, Scientific Reports, 3, 2770, doi:10.1038/srep02770, 2013.

Grams, C. M., Binder, H., Pfahl, S., Piaget, N., and Wernli, H.: Atmospheric processes triggering the central European floods in June 2013, Nat. Hazards Earth Syst. Sci., 14, 1691-1702, doi:10.5194/nhess-14-1691-2014, 2014.

Hoskins, B. J., Draghici, I., and Davies, H. C.: A new look at the $\Omega$-equation, Q. J. Roy. Meteor. Soc., 104, 31-38, 1978.

Ionita, M., Lohmann, G., and Rimbu, N.: Prediction of spring Elbe discharge based on stable teleconnections with winter global temperature and precipitation, J. Climate, 21, 6215-6226, 2008.

Ionita, M., Lohmann, G., Rimbu, N., and Chelcea, S.: Interannual variability of Rhine River streamflow and its relationship with large-scale anomaly patterns in spring and autumn, J. Hydrometeorol., 13, 172-188, 2012.

Ionita, M., Dima, M., Lohmann, G., Scholz, P., and Rimbu, N.: Predicting the June 2013 European flooding based on precipitation, soil moisture and sea level pressure, J. Hydrometeorol., 16, 598614, doi:10.1175/JHM-D-14-0156.1, 2015.

Jacobeit, J., Glaser, R., Luterbacher, J., and Wanner, H.: Links between flood events in central Europe since AD 1500 and largescale atmospheric circulation modes, Geophys. Res. Lett., 30, 1172, doi:10.1029/2002GL016433, 2003.

Krichak, S. O., Breitgand, J. S., Gualdi, S., and Feldstein, S.: Teleconnection-extreme precipitation relationships over the Mediterranean region, Theor. Appl. Climatol., 117, 679-692, doi:10.1007/s00704-013-1036-4, 2014.

Lavers, D. A., Villarini, G., Allan, R. P., Wood, E. F., and Wade, A. J.: The detection of atmospheric rivers in atmospheric reanalysis and their links to British winter floods and the largescale climatic circulation, J. Geophys. Res., 117, D20106, doi:10.1029/2012JD018027,2012.

Ludwig, R., Taschner, S., and Mauser, W.: Modelling floods in the Ammer catchment: limitations and challenges with a coupled meteo-hydrological model approach, Hydrol. Earth Syst. Sci., 7, 833-847, doi:10.5194/hess-7-833-2003, 2003.

Peña, J. C., Schulte, L., Badoux, A., Barriendos, M., and BarreraEscoda, A.: Influence of solar forcing, climate variability and modes of low-frequency atmospheric variability on summer 
floods in Switzerland, Hydrol. Earth Syst. Sci., 19, 3807-3827, doi:10.5194/hess-19-3807-2015, 2015.

Petrow, T. and Merz, B.: Trends in flood magnitude frequency and seasonality in Germany in the period 1951-2002, J. Hydrol., 371, 129-141, doi:10.1016/j.jhydrol.2009.03.024, 2009.

Schillereff, D., Chiverrell, R., Macdonald, N., and Hooke, J.: Flood stratigraphies in lake sediments: a review, Earth-Sci. Rev., 135, 17-37, doi:10.1016/j.earscirev.2014.03.011, 2014.

Schlemmer, L., Martius, O., Sprenger, M., Schwierz, C., and Twitchett, A.: Disentangling the forcing mechanisms of heavy precipitation event along the Alpine south side using potential vorticity inversion, Mon. Weather Rev., 138, 2336-2353, doi:10.1175/2009MWR3202.1, 2010.

Swierczynski, T., Brauer, A., Lauterbach, S., Martín-Puertas, C., Dulski, P., von Grafenstein, U., and Rohr, C.: A 1600 yr seasonally resolved record of decadal-scale flood variability from the Austrian Pre-Alps, Geology, 40, 1047-1050, 2012.

Toreti, A., Xoplaki, E., Maraun, D., Kuglitsch, F. G., Wanner, H., and Luterbacher, J.: Characterisation of extreme winter precipitation in Mediterranean coastal sites and associated anomalous atmospheric circulation patterns, Nat. Hazards Earth Syst. Sci., 10, 1037-1050, doi:10.5194/nhess-10-1037-2010, 2010.
Toreti, A., Schneuwly-Bollschweiler, M., Stoffel, M., and Luterbacher, J.: Atmospheric forcing of debris flows in the southern Swiss Alps, J. Appl. Meteorol. Clim., 52, 1554-1560, doi:10.1175/JAMC-D-13-077.1, 2013.

Zängl, G.: Interaction between dynamics and cloud microphysics in orographic precipitation enhancement: a high-resolution modeling study of two North Alpine heavy-precipitation events, Mon. Weather Rev., 135, 2817-2840, 2007.

Zolina, O., Simmer, C., Kapala, A., Gulev, S., and Maechel, H.: Seasonally dependent changes of precipitation extremes over Germany since 1950 from a very dense observational network, J. Geophys. Res.-Atmos., 113, D06110, doi:10.1029/2007JD008393, 2008.

Winschall, A., Pfahl, S., Sodemann, H., and Wernli, H.: Comparison of Eulerian and Lagrangian moisture source diagnostics the flood event in eastern Europe in May 2010, Atmos. Chem. Phys., 14, 6605-6619, doi:10.5194/acp-14-6605-2014, 2014. 